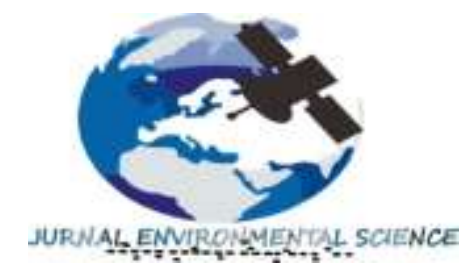

Jurnal Environmental Science

Volume 4 Nomor 1 Oktober 2021

p-ISSN : 2654-4490 dan e-ISSN : 2654-9085

Homepage at : ojs.unm.ac.id/JES

E-mail:jes@unm.ac.id

\title{
PEMETAAN TINGKAT KEKRITISAN UNTUK DAERAH RESAPAN (WILAYAH STUDI KASUS KOTA PAREPARE)
}

\author{
Uca $^{1}$, Sukri Nyompa ${ }^{2}$, Novita Citra Rahayu ${ }^{3}$ \\ ${ }^{12}$ Jurusan Geografi Fakultas Ilmu dan Pengetahuan Alam \\ Universitas Negeri Makassar \\ Email : ucasideng@yahoo.com ${ }^{1}$,sukri_nyompa@yahoo.co.id,nvtctrrhy@gmail.com ${ }^{3}$
}

\begin{abstract}
High population growth, especially in urban areas, increases community needs which trigger land use changes. This causes a decrease in the quality and carrying capacity of the land which has an impact on reducing the rainwater catchment area. One of the problems that often occurs in urban areas is that infiltration conditions are no longer optimal in storing water, causing rainwater to pool on the surface and flooding occurs. The development of remote sensing technology and geographic information systems has made it possible to study the spatial pattern of critical distribution of water catchment areas in a wide scope. This study aims to determine the condition of the potential and actual catchment areas, as well as the criticality level of the water catchment area in the City of Parepare. The method used is scoring and overlaying the parameters of slope, rainfall, and soil type to produce a map of potential catchment areas. The map of the actual catchment area condition was obtained based on the interpretation of the sentinel-2 image. The two resulting maps were then compared to determine the criticality level of the catchment area in Parepare City. The results show that Parepare City has a potential infiltration condition which is dominated by a small potential area of $69.07 \mathrm{~km}^{2}$ and an actual catchment area which is dominated by a rather large infiltration capacity of $30.47 \mathrm{~km}^{2}$. The most dominant criticality level in Parepare City is both an area of $59.24 \mathrm{~km}^{2}$ which is randomly distributed.
\end{abstract}

Keywords: Actual; Critical of Catchment Areas; Potential.

\begin{abstract}
ABSTRAK
Pertumbuhan penduduk yang tinggi khususnya di kawasan perkotaan meningkatkan kebutuhan masyarakat yang memicu terjadinya perubahan penggunaan lahan. Hal tersebut menyebabkan terjadinya penurunan kualitas dan daya dukung lahan yang berdampak pada berkurangnya daerah resapan air hujan. Salah satu permasalahan yang sering terjadi pada kawasan perkotaan yakni kondisi resapan yang tidak lagi optimal dalam menampung air sehingga membuat air hujan tergenang di permukaan dan terjadi banjir. Perkembangan teknologi penginderaan jauh dan sistem informasi geografis telah memungkinkan mengkaji pola spasial persebaran kekritisan daerah resapan air dalam cakupan yang luas. Penelitian ini bertujuan untuk mengetahui kondisi daerah resapan potensial dan aktual, serta tingkat kekritisan daerah resapan air di Kota Parepare. Metode yang digunakan adalah skoring dan overlay antara parameter kemiringan lereng, curah hujan, dan jenis tanah untuk menghasilkan peta daerah resapan potensial. Peta kondisi daerah resapan aktual diperoleh berdasarkan hasil interpretasi citra sentinel-2. Kedua peta yang dihasilkan kemudian dibandingkan untuk mengetahui tingkat kekritisan daerah resapan di Kota Parepare. Hasil menunjukkan Kota Parepare memiliki kondisi resapan potensial yang didominasi oleh potensial kecil seluas $69,07 \mathrm{~km}^{2}$ dan kondisi daerah resapan aktual yang didominasi oleh kemampuan peresapan agak besar seluas $30,47 \mathrm{~km}^{2}$. Tingkat kekritisan paling dominan di Kota Parepare yakni baik seluas 59,24 $\mathrm{km}^{2}$ yang tersebar acak.
\end{abstract}

Kata Kunci : Aktual, Kekritisan Daerah Resapan, Potensial. 


\section{PENDAHULUAN}

Tingginya tingkat pertumbuhan penduduk khususnya di kawasan perkotaan mengakibatkan peningkatan kebutuhan masyarakat di bidang permukiman dan infrastruktur dasar, serta yang tidak kalah penting yaitu ketersediaan air. Air merupakan sumber daya alam yang mutlak diperlukan untuk keberlangsungan hidup manusia di berbagai sektor kehidupan. Saat ini, kegunaan air bagi manusia tidak hanya terbatas pada pemenuhan kebutuhan pokok untuk konsumsi saja, Adi (2009) menjelaskan bahwa terjadi pergeseran nilai dan kegunaan untuk kepentingan lain seperti industri, tenaga listrik, perikanan, pertanian, transportasi, dan pariwisata. Implikasinya, kompetisi terkait ketersediaan air dalam berbagai kepentingan meningkat dan akan semakin meningkat ketika ketersediaan air tidak cukup memadai dari segi kuantitas.

Ketersediaan air dari segi kuantitas sangat bergantung pada penggunaan lahan suatu wilayah. Dewasa ini pembangunan telah mengalami kemajuan yang pesat dan menimbulkan perubahan fungsi lahan, dalam hal ini yang dimaksud ialah perubahan penggunaan lahan yang sangat mempengaruhi kualitas dan daya dukung lahan utamanya fungsi tata air. Menurut data dari Tata Ruang Dinas PUPR Kota Parepare, tren peningkatan pembangunan rumah tinggal permanen berdasarkan data IMB tahun 2017 tercatat sebanyak 756 unit, tahun 2018 sebanyak 1664 unit, tahun 2019 sebanyak 1545 unit, dan tahun 2020 sebanyak 1155 unit. Sebagai konsekuensi dari pertumbuhan penduduk dan perubahan tutupan alami di wilayah perkotaan yang secara terus-menerus menjadi wilayah terbangun, perubahan ini berkontribusi terhadap pengurangan daerah resapan air wilayah kota akibat berkurangnya tutupan vegetasi, sehingga terjadi pertambahan beban terhadap daya dukung lingkungan perkotaan.

Dalam konteks perkotaan, kawasan daerah resapan air penting untuk menjaga keseimbangan siklus hidrologi agar tidak terganggu dan menimbulkan dampak buruk bagi kehidupan masyarakat seperti fenomena bencana banjir. Umumnya banjir disebabkan karena aliran air maupun drainase tidak mampu menampung debit air sehingga air meluap. Banjir merupakan masalah yang kerap terjadi di lingkungan perkotaan dengan wilayah terbangun yang menggunakan material-material kedap air seperti aspal, semen, dan beton. Material tersebut mengurangi daerah resapan air sehingga dapat memicu terjadinya aliran permukaan (surface run off). Daerah resapan air adalah daerah tempat meresapnya air hujan ke dalam tanah yang selanjutnya menjadi air tanah. Putri dan Purwadio (2013) menyatakan bahwa perubahan daerah resapan menjadi lahan terbangun dapat menyebabkan penurunan volume air tanah. Hal ini menggambarkan bahwa daerah resapan berperan penting dalam mengatur sistem transportasi air melalui kemampuannya mengendalikan air permukaan dengan meresapkan air ke dalam tanah sehingga dapat mengatasi masalah banjir dan kekeringan.

Perubahan daerah resapan menjadi lahan terbangun menyebabkan terbentuknya lahan kritis yaitu lahan yang saat ini tidak produktif karena pengelolaan dan penggunaan tanah yang kurang memperhatikan syarat-syarat konservasi tanah dan air sehingga menimbulkan erosi, kerusakankerusakan kimia, fisik, tata air dan lingkungannya (Soedarjanto dan Syaiful, dalam Wirosoedarmo R, 2007). Hal tersebut menunjukkan bahwa perubahan penggunaan lahan dari kawasan tidak terbangun menjadi kawasan terbangun memberikan dampak yang signifikan terhadap kondisi resapan air utamanya dalam daerah perkotaan.

Salah satu permasalahan yang sering terjadi pada daerah perkotaan yakni kondisi resapan yang tidak lagi optimal dalam menampung air ketika intensitas curah hujan tinggi sehingga menyebabkan air sungai meluap. Kota Parepare merupakan salah satu kota yang telah mengalami perubahan kapasitas akibat berkurangnya daya dukung lahan sehingga tidak banyak menyerap air ketika hujan turun (Mulyadi, 2019). Imbasnya, beberapa tahun terakhir ini sejumlah daerah di Kota Parepare sering mengalami banjir saat musim hujan tiba. Dilansir dari artikel kompas.tv menyatakan bahwa curah hujan yang tinggi mengakibatkan sejumlah sungai meluap, hal ini berdampak pada ratusan rumah warga di 4 kecamatan di Kota Parepare terendam banjir.

Saat ini, perkembangan teknologi penginderaan jauh dan sistem informasi geografis pun telah memungkinkan pengkajian pola spasial persebaran kekritisan daerah resapan air dalam cakupan yang luas. Mengingat pentingnya menjaga agar kondisi daerah resapan tetap optimal, maka juga perlu diketahui estimasi persebaran wilayah tingkat kekritisan daerah resapan dengan menganalisis kondisi resapan daerah potensial dan daerah aktual. Berdasarkan pertimbangan di atas, maka dipandang perlu dilakukan penelitian tentang "Pemetaan Tingkat Kekritisan Daerah Resapan, Wilayah Studi Kasus Kota Parepare" 


\section{METODE}

\section{Lokasi dan Waktu Penelitian}

Penelitian ini dilakukan di Kota Parepare Provinsi Sulawesi Selatan yang memiliki luas sebesar $99,33 \mathrm{~km}^{2}$.

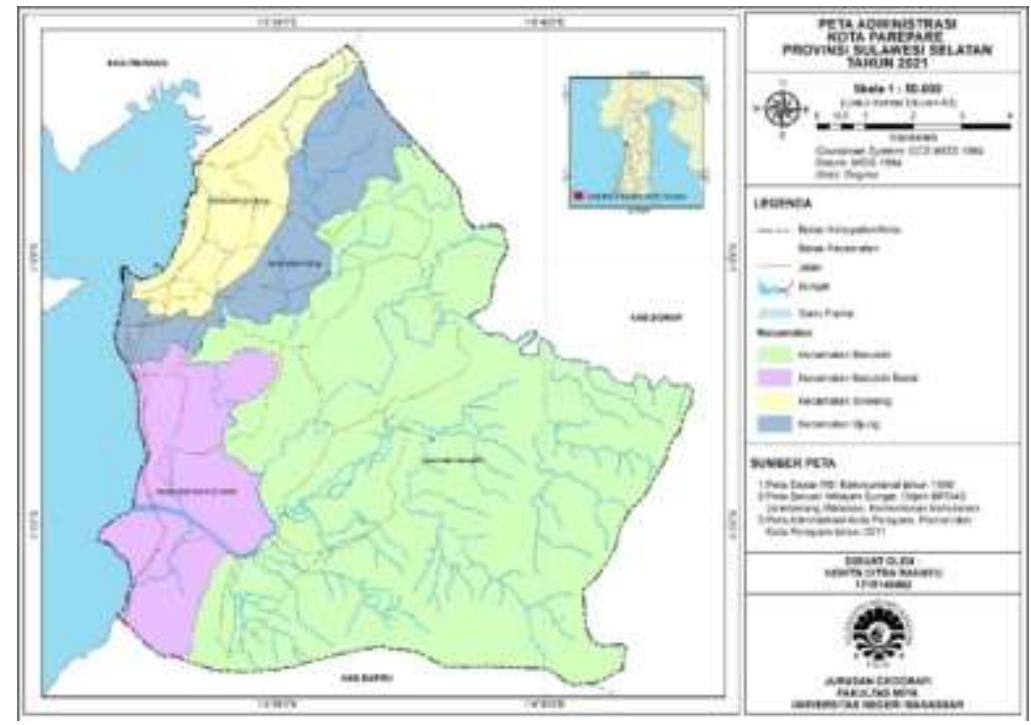

Gambar 1. Lokasi Penelitian

\section{Definisi Operasional Variabel}

Untuk menghindari kesalahan interpretasi variabel penelitian, maka pengoperasian variabel didefinisikan sebagai berikut:

a. Kemiringan lereng adalah kemunculan suatu permukaan alam karena adanya perbedaan ketinggian antara dua lokasi. Sudut yang membentuk dua ketinggian ini biasa disebut sudut kemiringan.

b. Jenis tanah adalah kumpulan tubuh-tubuh alam hasil pengalihragaman (transformation) bahan mineral dan organik yang berlangsung di muka daratan bumi di bawah pengaruh faktor-faktor lingkungan yang bekerja selama waktu sangat panjang.

c. Curah hujan adalah ketinggian air hujan yang jatuh pada tempat yang datar selama periode waktu tertentu yang pengukurannya menggunakan satuan tinggi di atas permukaan tanah horizontal yang diasumsikan tidak terjadi infiltrasi, run off, maupun evaporasi.

d. Penggunaan lahan adalah campur tangan manusia baik secara permanen atau periodik terhadap lahan dengan tujuan untuk memenuhi kebutuhan, baik kebutuhan kebendaan, spiritual maupun gabungan keduanya.

e. Lahan kritis adalah lahan yang kualitas dan fungsi lahannya berkurang sehingga memiliki daya serap yang tidak sesuai dengan kapasitas optimalnya (kondisi potensial).

\section{Alat dan Bahan Penelitian}

Alat dan bahan yang digunakan dalam penelitian ini dapat dilihat pada tabel di bawah ini : 
Tabel 1. Alat dan Bahan Penelitian

\begin{tabular}{llll}
\hline No & \multicolumn{1}{c}{ Nama Alat/Bahan } & Jumlah & \multicolumn{1}{c}{ Kegunaan } \\
\hline 1 & Double ring infiltrometer & 1 buah & Sebagai data acuan (peta dasar) \\
2 & Stopwatch & 1 buah & Mengukur waktu \\
3 & Global Positioning System & 1 buah & Plotting lokasi \\
4 & Alat tulis menulis & 1 paket & Mencatat hasil pengamatan \\
5 & Pita ukur & 1 buah & Peliputan objek \\
6 & Galon/jergen & 4 buah & Menampung air \\
8 & Kamera & 1 buah & Dokumentasi \\
9 & Data curah hujan & 10 tahun & Peta curah hujan \\
10 & Data jenis tanah & & Peta jenis tanah \\
11 & SRTM & & Peta kemiringan lereng \\
12 & Citra Sentinel-2 & & Peta penggunaan lahan \\
13 & Perangkat komputer & & \\
& a. Hardware & 1 buah & Pengelolaan data dan pembuatan \\
& 1) Laptop & & peta \\
2) Mouse & & \\
b. Software & & \\
1) Google Earth & & \\
2) ArcGIS 10.3 & & \\
\hline
\end{tabular}

\section{Teknik Analisis Data}

Adapun teknik analisis data dilakukan dengan skoring dan overlay antara parameter kemiringan lereng, curah hujan, dan jenis tanah untuk menghasilkan peta daerah resapan potensial. Peta kondisi daerah resapaan aktual diperoleh berdasarkan hasil interpretasi citra Sentinel-2. Kedua peta yang dihasilkan kemudian dibandingkan untuk mengetahui tingkat kekritisan daerah resapan di Kota Parepare.

\section{Tahapan Penelitian}

Tahapan penelitian yang dilakukan dalam penelitian ini, yaitu :

a. Tahapan Persiapan dan Pengumpulan Data

Tahap persiapan dengan melakukan tinjauan pustaka untuk mendukung penelitian yang dilakukan. Kemudian melakukan observasi untuk mengetahui kondisi lokasi penelitian. Adapun teknik pengumpulan data dilakukan dengan kajian literatur yaitu mempelajari beberapa referensi buku, jurnal, penelitian-penelitian sebelumnya yang memiliki tema yang sama dengan tujuan untuk memahami masalah yang ada serta menentukan parameter-parameter yang digunakan untuk analisis tingkat kekritisan daerah resapan yang selanjutnya akan dilakukan pengumpulan data yang sesuai dengan parameter-parameter yang digunakan dalam pemetaan tingkat kekritisan daerah resapan. Pengumpulan data baik data primer dan data sekunder dilakukan melalui beberapa sumber

\section{b. Tahapan Pra Pengolahan Data}

Tahap pra pengolahan data merupakan tahap yang dilakukan untuk memperoleh informasi terkait parameter-parameter yang dibutuhkan untuk pemetaan tingkat kekritisan daerah resapan di Kota Parepare menggunakan data-data yang telah dipersiapkan. Parameter untuk pemetaan tingkat kekritisan daerah resapan berdasarkan Menteri Kehutanan (P.32/MENHUT-II/2009) tentang Tata Cara Penyusunan Rencana Teknik Rehabilitasi Hutan dan Lahan Daerah Aliran Sungai (RTKRHLDAS) terbagi menjadi pemetaan kondisi resapan potensial yang terdiri dari kemiringan lereng, curah hujan, dan jenis tanah dan parameter yang termasuk dalam pemetaan kondisi resapan aktual yakni penggunaan lahan.

\section{c. Tahapan Pengolahan dan Penyajian Data}

Tahap pengolahan data merupakan tahap dalam penentuan tingkat kekritisan daerah resapan. Setelah didapatkan peta kondisi resapan potensial dan aktual kemudian kedua peta tersebut digunakan untuk menentukan kondisi kekritisan daerah resapan. Kedua peta tersebut dioverlay dan kemudian 
skor total dari kedua peta tersebut dibandingkan untuk menentukan tingkat kekritisan daerah resapannya menggunakan matriks penentuan tingkat kekritisan daerah resapan berikut:

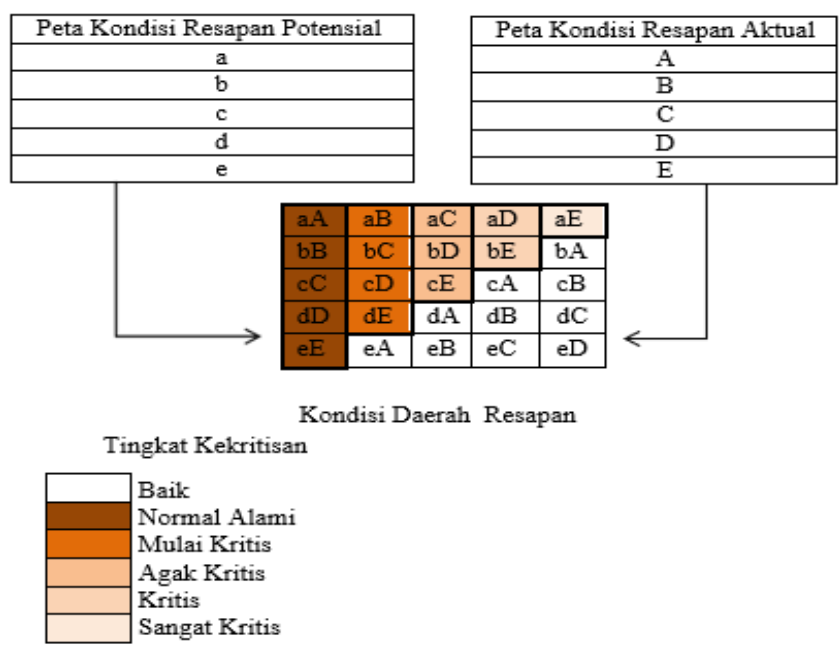

Gambar 2. Matriks Penentuan Tingkat Kekritisan Daerah Resapan

(Sumber: Penentuan Kondisi Resapan dalam Peraturan Menteri Kehutanan (P.32/MENHUT-II/2009))

\section{d. Tahap Survey Lapangan}

Tahap ini dilakukan sebagai validasi pengolahan data setiap parameter atau variabel yang digunakan dalam menentukan kondisi resapan potensial maupun kondisi resapan aktual.

\section{HASIL DAN PEMBAHASAN}

\section{Kondisi Resapan Potensial dan Aktual Kota Parepare}

a. Kondisi Resapan Potensial

Pemetaan kondisi resapan potensial dilakukan untuk melihat kemampuan atau potensi peresapan dari beberapa faktor kondisi fisik lahan. Kondisi daerah resapan potensial dapat ditentukan berdasarkan kemiringan lereng, jenis tanah, dan curah hujan.

\section{1) Kemiringan Lereng}

Kemiringan lereng adalah kemunculan suatu permukaan alam karena adanya perbedaan ketinggian antara dua lokasi. Sudut yang membentuk dua ketinggian ini biasa disebut sudut kemiringan. Kemiringan lereng merupakan kondisi yang berpengaruh dalam daerah resapan. Lereng yang curam atau memiliki derajat kemiringan yang besar akan memungkinkan hujan yang jatuh lebih banyak menjadi limpasan permukaan dan hanya sedikit yang meresap ke dalam tanah. Hal ini dipengaruhi oleh gaya gravitasi pada air di lereng yang lebih curam lebih besar sehingga air yang belum sempat terserap akan menjadi limpasan. Keadaan sebaliknya terjadi pada lereng datar yakni memungkinkan mengalami infiltrasi yang besar. Luas tiap kelas kemiringan lereng di Kota Parepare disajikan dalam tabel 2 berikut:

Tabel 2. Luas Tiap Kelas Lereng di Kota Parepare

\begin{tabular}{lcccc}
\hline \multicolumn{1}{c}{ Kemiringan Lereng $(\%)$} & Luas $\left(\mathrm{km}^{2}\right)$ & Persentase $(\%)$ & Skor Infiltrasi & Notasi \\
\hline$<8$ & 18,20 & 18,37 & 5 & $\mathrm{a}$ \\
$8-15$ & 21,72 & 21,92 & 4 & $\mathrm{~b}$ \\
$15-25$ & 20,50 & 20,70 & 3 & $\mathrm{c}$ \\
$25-40$ & 20,36 & 20,56 & 2 & $\mathrm{~d}$ \\
$>40$ & 18,28 & 18,46 & 1 & $\mathrm{e}$ \\
\hline
\end{tabular}

(Sumber: Hasil analisis, 2021) 
Kemiringan lereng dengan kondisi bergelombang hingga curam memiliki persentase luas yang hampir sama yaitu sebesar 20,70 persen dan 20,56 persen. Sedangkan kemiringan lereng $<8 \%$ dan $>40 \%$ juga memiliki persentase luas yang hampir sama yaitu kurang lebih 18 persen atau masingmasing seluas $18,37 \mathrm{~km}^{2}$ dan $18,46 \mathrm{~km}^{2}$.

Hal tersebut menunjukkan bahwa kondisi topografi Kota Parepare secara umum memiliki kelerengan landai hingga bergelombang yang berdampak baik dalam proses infiltrasi, dikarenakan air yang jatuh terlebih dahulu akan menggenang di atas permukaan tanah dan kemudian akan terinfiltrasi ke dalam tanah. Namun, untuk kelas lereng curam hingga sangat curam yang luasnya juga tidak sedikit dapat menyebabkan minimnya air yang dapat terinfiltrasi, karena sebagian besar air hujan akan mengalami aliran permukaan.

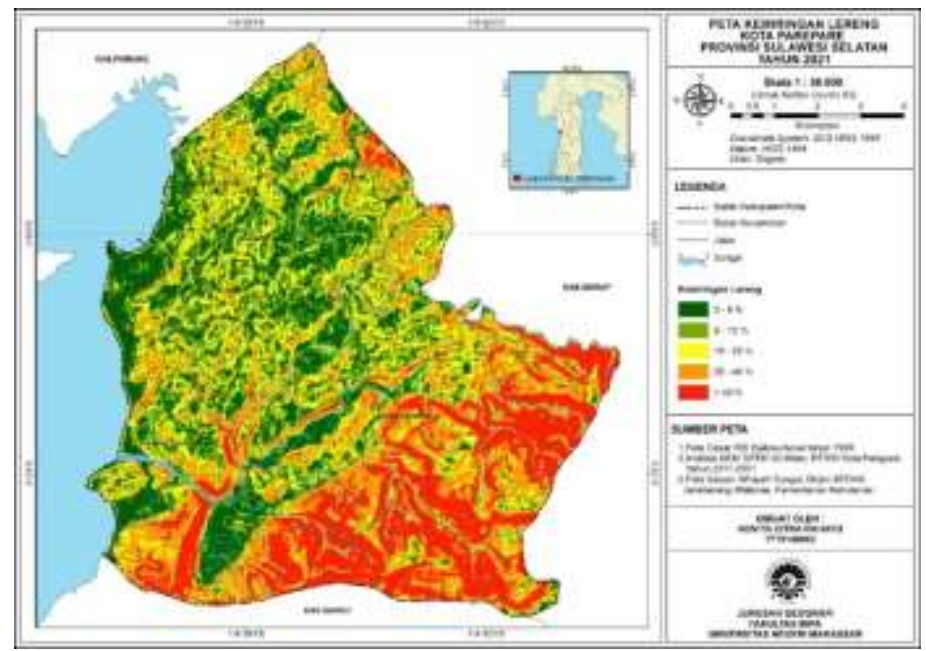

Gambar 3. Peta Kemiringan Lereng Kota Parepare.

\section{2) Jenis Tanah}

Jenis dan distribusi jenis tanah digunakan untuk mengetahui kemampuan tanah dalam meresapkan air dan dinyatakan dalam skor tertentu untuk menentukan kondisi resapan potensial di Kota Parepare. Berbagai jenis tanah mempunyai kepekaan terhadap laju infiltrasi yang berbeda-beda. Hal ini dipengaruhi oleh kondisi dari tekstur tanah itu sendiri. Jenis tanah yang memiliki tekstur kasar akan cenderung lebih meresapkan air ke dalam tanah, sedangkan jenis tanah yang memiliki tekstur halus akan cenderung lebih sulit atau hanya mampu meresapkan sedikit air ke dalam tanah. Berdasarkan hubungannya dengan kemampuan infiltrasi, jenis tanah di Kota Parepare memiliki potensi meresapkan air yang sangat lambat. Luasan setiap jenis tanah yang terdapat di Kota Parepare disajikan dalam tabel 3 berikut:

Tabel 3. Luas Setiap Jenis Tanah di Kota Parepare

\begin{tabular}{lcccc}
\hline \multicolumn{1}{c}{ Jenis Tanah } & $\begin{array}{c}\text { Luas } \\
\left(\mathrm{km}^{2}\right)\end{array}$ & $\begin{array}{c}\text { Persentase } \\
(\%)\end{array}$ & $\begin{array}{c}\text { Skor } \\
\text { Infiltrasi }\end{array}$ & Notasi \\
\hline Aluvial Hidromorf & 5,78 & 6,34 & 1 & $\mathrm{e}$ \\
Aluvial Kelabu Olit & 0,29 & 0,31 & 1 & $\mathrm{e}$ \\
Aluvial Kelabuan Kekuningan & 0,13 & 0,15 & 1 & $\mathrm{e}$ \\
Kompleks Mediteran Coklat Regosol dan & 23,05 & 25,27 & 1 & $\mathrm{e}$ \\
Litosol & & & & $\mathrm{e}$ \\
Regosol Coklat & 61,97 & 67,93 & 1 & $\mathrm{e}$ \\
\hline
\end{tabular}

(Sumber: Hasil analisis, 2021)

Berdasarkan hasil analisis laboratorium, jenis tanah Regosol coklat memiliki tekstur lempung, jenis tanah Kompleks mediteran coklat regosol \& Litosol memiliki tekstur liat, jenis tanah Aluvial hidromorf memiliki tekstur lempung berpasir, jenis tanah Aluvial kelabu olit memiliki tekstur lempung, dan jenis tanah Aluvial kelabuan Kekuningan memili tekstur pasir berlempung. Sehingga 
dapat diketahui bahwa jenis tanah Kota Parepare memiliki tekstur yang halus, sedang, agak kasar, hingga kasar.

Hal tersebut mempengaruhi kemampuan tanah dalam meloloskan air yang dibuktikan pada hasil pengukuran lapangan menggunakan alat double ring infiltrometer. Hasil pengukuran menunjukkan bahwa semua jenis tanah di Kota Parepare memiliki nilai laju infiltrasi $<0,1 \mathrm{~cm} / \mathrm{jam}$ sehingga termasuk dalam kelas infiltrasi dengan kriteria menurut Konhke (1968) sangat lambat.

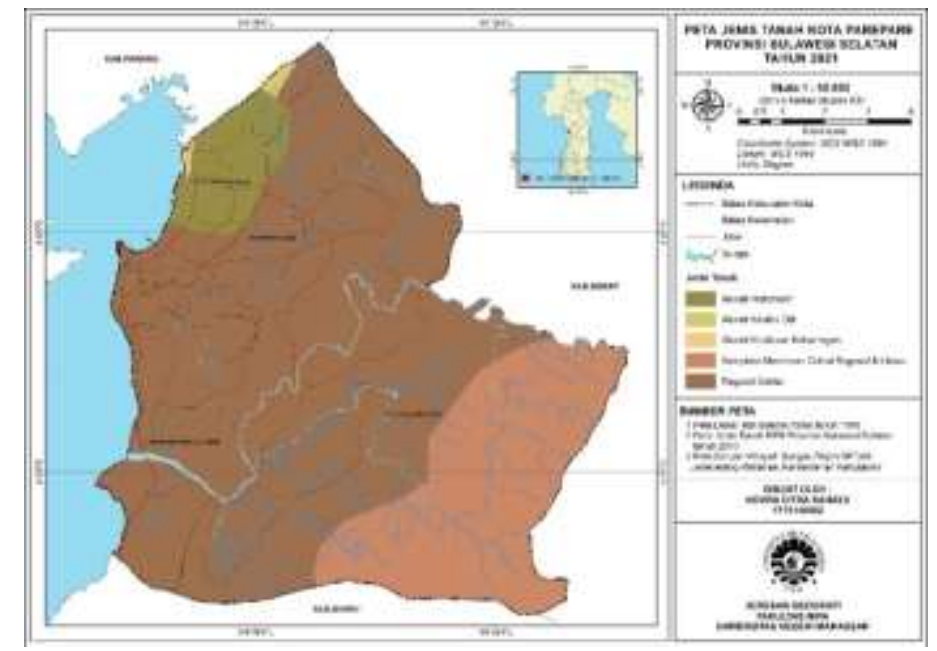

Gambar 4. Peta Jenis Tanah Kota Parepare.

\section{3) Curah Hujan}

Curah hujan merupakan faktor yang tergolong penting dalam menentukan peresapan atau infiltrasi yakni dengan sebagai input bagi proses infiltrasi. Curah hujan yang semakin besar memungkinkan potensi resapan yang semakin besar pula dan begitu pula sebaliknya, semakin kecil curah hujan maka semakin kecil pula potensi resapannya. Peta curah hujan dihasilkan dari interpolasi curah hujan dari beberapa titik stasiun di dalam dan sekitar Kota Parepare. Interpolasi curah hujan di Kota Parepare dilakukan menggunakan 3 stasiun hujan yakni stasiun Bukit Harapan, Bulu Dua, dan Palanro. Data curah hujan ketiga stasiun tersebut disajikan dalam tabel berikut:

Tabel 4. Luas Setiap Jenis Tanah di Kota Parepare

\begin{tabular}{llc}
\hline No. & \multicolumn{1}{c}{ Stasiun Curah Hujan } & Curah Hujan (mm/tahun) \\
\hline 1. & Bukit Harapan & 2367,048 \\
2. & Bulu Dua & 1737,487 \\
3. & Palanro & 4696,797 \\
\hline
\end{tabular}

(Sumber: Data Curah Hujan BMKG, 2021)

Interpolasi curah hujan dilakukan menggunakan metode IDW. Metode ini digunakan karena memiliki tingkat keakuratan yang lebih baik dalam memprediksi persebaran curah hujan dibandingkan metode interpolasi lain. Hal ini dibuktikan berdasarkan nilai hasil interpolasi curah hujan yang lebih mendekati curah hujan dilapangan berdasarkan data dari stasiun hujan.

Berdasarkan peta curah hujan tersebut diketahui curah hujan yang dominan turun di Kota Parepare adalah curah hujan 2000 - $3000 \mathrm{~mm}$ di daerah seluas $45,95 \mathrm{~km}^{2}$ atau $46,46 \%$ dari total luas Kota Parepare. Sedangkan daerah dengan curah hujan $1000-2000 \mathrm{~mm}$ seluas $35 \mathrm{~km}^{2}$ dan daerah dengan curah hujan $>4000 \mathrm{~mm}$ seluas $17,96 \mathrm{~km}^{2}$. Luasan daerah cakupan curah hujan Kota Parepare disajikan dalam tabel 5 berikut : 
Tabel 5. Luas Setiap Jenis Tanah di Kota Parepare

\begin{tabular}{lcccc}
\hline \multicolumn{1}{c}{ Curah Hujan $(\mathrm{mm})$} & Luas $\left(\mathrm{km}^{2}\right)$ & Persentase $(\%)$ & Skor Infiltrasi & Notasi \\
\hline$>4000$ & 17,96 & 18,16 & 5 & $\mathrm{a}$ \\
$2000-3000$ & 45,95 & 46,46 & 3 & $\mathrm{c}$ \\
$1000-2000$ & 35,00 & 35,39 & 2 & $\mathrm{~d}$ \\
\hline
\end{tabular}

(Sumber: Hasil analisis, 2021)

Hasil interpolasi kemudian dikelaskan berdasarkan hubungannya dengan infiltrasi, hasilnya diketahui terdapat tiga kelas curah hujan yang turun di Kota Parepare yakni 1000 - 2000 mm, 2000 3000 mm, dan >4000 mm. Peta curah hujan Kota Parepare disajikan dalam Gambar 5.

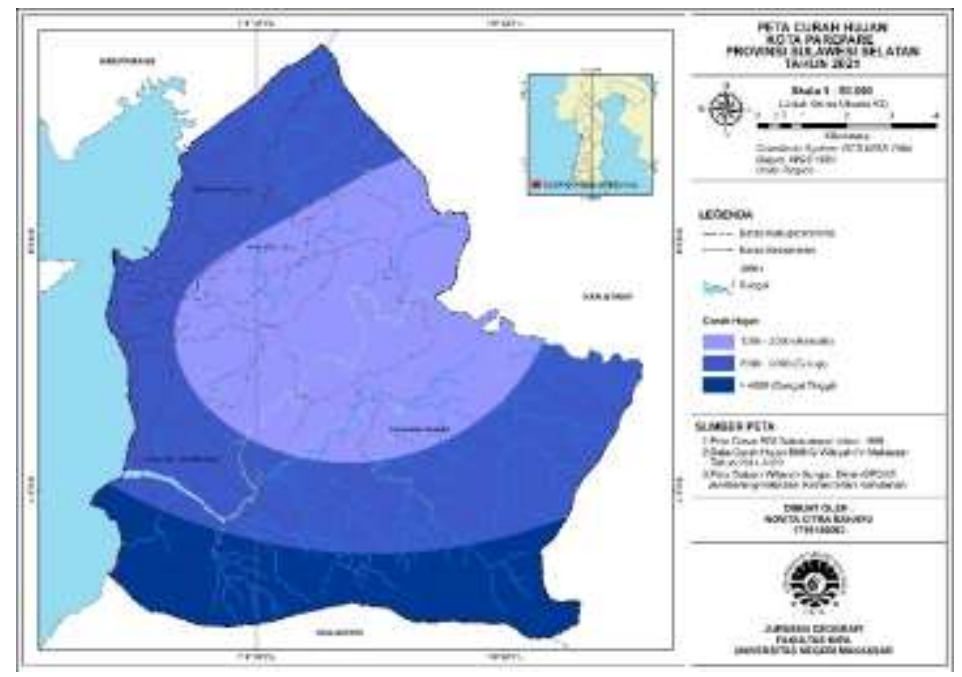

Gambar 5. Peta Curah Hujan Kota Parepare

Setiap kondisi dari lereng, jenis tanah dan curah hujan memiliki kemampuan tersendiri dalam meresapkan air ke dalam tanah. Suatu lahan dengan kondisi fisik lahan yang baik memiliki pengaruh terhadap kondisi peresapan potensial yang besar, dan keadaan sebaliknya akan menunjukkan kondisi resapan potensial yang kecil. Selain itu, kondisi resapan potensial yang baik juga dicirikan dengan tingginya skor dari masing-masing faktor fisik lahan yang menunjukkan besarnya potensi kondisi lahan tersebut dalam meresapkan air.

Pemetaan kondisi daerah resapan potensial di Kota Parepare dilakukan dengan melakukan overlay terhadap 3 parameter yang digunakan yakni peta kemiringan lereng, peta curah hujan, dan peta jenis tanah. Penentuan kondisi daerah resapan potensial didasarkan pada jumlah skor total dari ketiga parameter yang digunakan. Berdasarkan hasil overlay, diketahui Kota Parepare memiliki kondisi daerah resapan potensial yang terbagi menjadi tiga kondisi yakni kondisi potensial resapan sangat kecil, kecil, dan sedang.

Berdasarkan hasil analisis yang dilakukan maka diperoleh peta kondisi resapan potensial dan kondisi resapan aktual yang kemudian menghasilkan peta tingkat kekritisan daerah resapan air di Kota Parepare. Hasil analisis menunjukkan perbedaan kondisi resapan potensial dipengaruhi oleh parameter-parameter kondisi fisik yang digunakan yakni curah hujan, jenis tanah, dan kemiringan lereng. Seperti pada Kecamatan Soreang yang memiliki kemampuan resapan sedang memiliki kondisi lereng yang didominasi oleh kemiringan $0-25 \%$, kondisi curah hujan yang turun yakni $2000-3000$ $\mathrm{mm} / \mathrm{tahun}$, dan jenis tanah dominan alluvial hidromorf yang tergolong sangat lambat dalam meresapkan air. Hal ini mengakibatkan Kecamatan Soreang didominasi oleh skor total dari ketiga parameter tersebut berkisar 9 hingga 11 dan termasuk kategori potensi resapan sedang. Peta kondisi resapan potensial Kota Parepare disajikan dalam Gambar 6. 


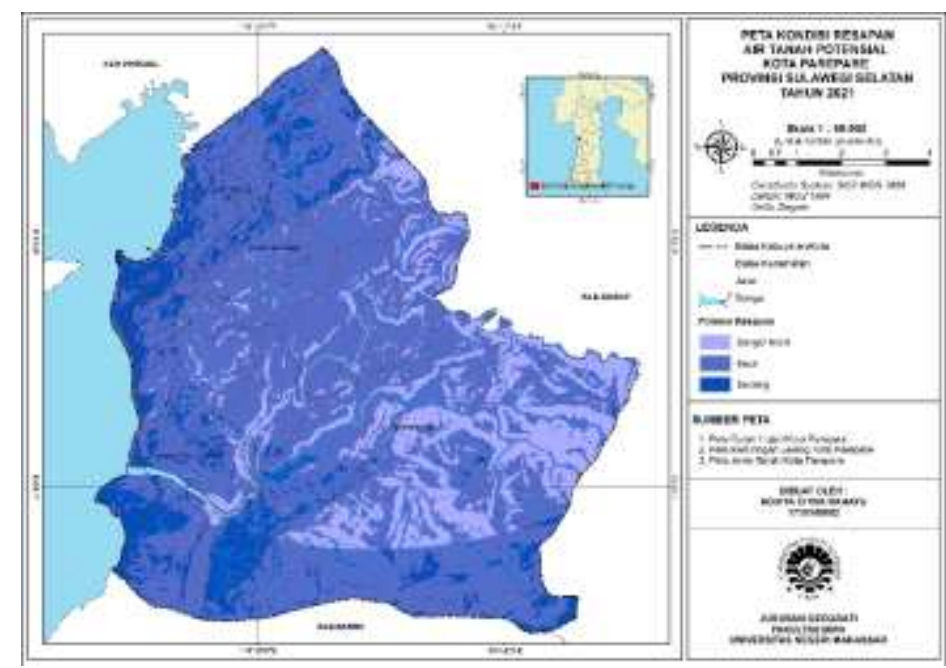

Gambar 6. Peta Kondisi Resapan Potensial Kota Parepare

Berdasarkan peta kondisi resapan potensial tersebut, dapat diketahui Kota Parepare didominasi oleh lahan dengan potensi resapan kecil. Hal ini dibuktikan dengan luas lahan dengan potensi resapan kecil di Kota Parepare sebesar $69,07 \mathrm{~km}^{2}$ atau $69,73 \%$ dari total luas. Lahan dengan potensi resapan kecil mencakup hampir seluruh kecamatan yang berada di Kota Parepare.

Lahan dengan kondisi potensi resapan sangat kecil di Kota Parepare memliki luas $16,21 \mathrm{~km}^{2}$. Sedangkan lahan yang memiliki potensi resapan sedang memiliki $13,77 \mathrm{~km}^{2}$. Luas lahan setiap kondisi peresapan disajikan dalam Tabel 6.

Tabel 6. Luas Lahan berdasarkan Potensial Resapan

\begin{tabular}{lcc}
\hline \multicolumn{1}{c}{ Potensi Resapan } & Luas $\left(\mathrm{km}^{2}\right)$ & Persentase $(\%)$ \\
\hline Sangat Kecil & 16,21 & 16,37 \\
Kecil & 69,07 & 69,73 \\
Sedang & 13,77 & 13,91 \\
\hline
\end{tabular}

(Sumber: Hasil Analisis, 2021)

\section{b. Kondisi Resapan Aktual}

Kondisi daerah resapan aktual mencerminkan besarnya permintaan terhadap kawasan daerah resapan air. Salah satu faktor yang dapat mempengaruhi kondisi daerah resapan aktual adalah penggunaan lahan.

\section{1) Penggunaan Lahan}

Peta penggunaan lahan merupakan peta yang digunakan untuk menentukan kondisi daerah resapan aktual di Kota Parepare. Peta penggunaan lahan diperoleh melalui interpretasi pada citra sentinel-2. Interpretasi yang dilakukan menggunakan metode interpretasi secara visual dengan membedakan setiap penggunaan lahan berdasarkan kunci-kunci interpretasi. Selain menggunakan kunci-kunci interpretasi, interpretasi penggunaan lahan di Kota Parepare yang dilakukan juga dipermudah dengan penggunaan komposit band yang menampilkan warna asli dari setiap objek. Pada citra sentinel-2 komposit yang digunakan yakni 432.

Berdasarkan hasil interpretasi, Kota Parepare memiliki 7 jenis penggunaan lahan. Penggunaan lahan yang terdapat di Kota Parepare hasil interpretasi yakni pertanian lahan kering, semak belukar, perkebunan, permukiman, tambak, sawah, dan hutan. Adapun luas penggunaan lahan di Kota Parepare disajikan dalam tabel 7 berikut : 
Tabel 7. Luas Penggunaan Lahan Hasil Interpretasi di Kota Parepare

\begin{tabular}{lccc}
\hline \multicolumn{1}{c}{ Potensi Resapan } & Luas $\left(\mathrm{km}^{2}\right)$ & Persentase $(\%)$ & Notasi \\
\hline Pertanian Lahan Kering & 17,92 & 18,31 & D \\
Semak Belukar & 7,76 & 7,93 & C \\
Perkebunan & 30,47 & 31,13 & B \\
Permukiman & 13,42 & 13,71 & E \\
Tambak & 0,92 & 0,94 & E \\
Sawah & 9,69 & 9,90 & E \\
Hutan & 17,69 & 18,07 & A \\
\hline
\end{tabular}

(Sumber: Hasil Analisis, 2021)

Beberapa kondisi yang dapat mencerminkan penggunaan lahan yang memiliki kondisi resapan baik adalah penggunaan lahan yang tidak tertutup atau memiliki kondisi tutupan vegetasi yang mendukunng peresapan air. Penggunaan lahan yang tampak paling mendominasi di Kota Parepare adalah penggunaan lahan jenis perkebunan seluas $30,47 \mathrm{~km}^{2}$. Adapun peta penggunaan lahan Kota Parepare disajikan dalam Gambar 7 berikut:

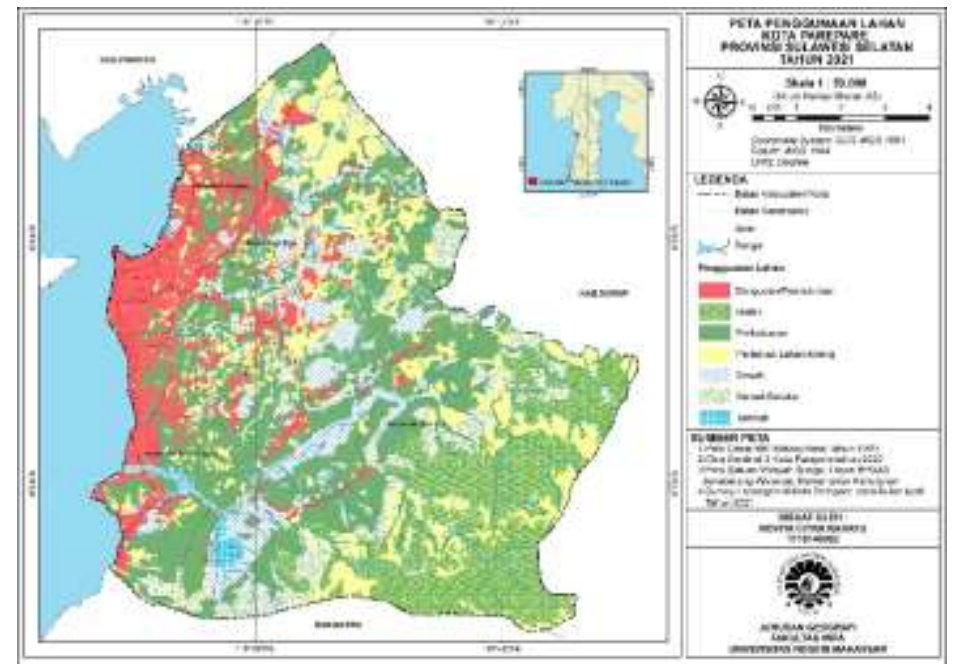

Gambar 7. Peta Penggunaan Lahan Kota Parepare

Penggunaan lahan yang mendukung sebagai daerah resapan air adalah penggunaan lahan yang memungkinkan dapat dengan mudah meloloskan air. Beberapa kondisi yang dapat mencerminkan penggunaan lahan yang memiliki kondisi resapan baik adalah penggunaan lahan yang tidak tertutup atau memiliki kondisi tutupan vegetasi yang mendukung peresapan air. Peta kondisi daerah resapan aktual diperoleh dari peta penggunaan lahan dengan menilai setiap penggunaan lahan terhadap kemampuannya meresapkan air.

Selain kondisi resapan potensial, kondisi daerah resapan aktual juga memiliki peran penting dalan penentuan tingkat kekritisan daerah resapan yakni menunjukkan besarnya permintaan terhadap kawasan daerah resapan air dalam hal ini berdasarkan penggunaan lahan yang ada. Penggunaan lahan yang termasuk dalam kelas kemampuan kecil yakni permukiman, tambak, dan sawah. Kondisi permukaan yang tertutup bangunan mengakibatkan air lebih sulit untuk meresap ke dalam tanah dan mengakibatkan memiliki kemampuan yang rendah dalam meloloskan air. Peta kondisi daerah resapan aktual Kota Parepare di Luas kondisi daerah resapan aktual di Kota Parepare disajikan dalam gambar 8 berikut: 


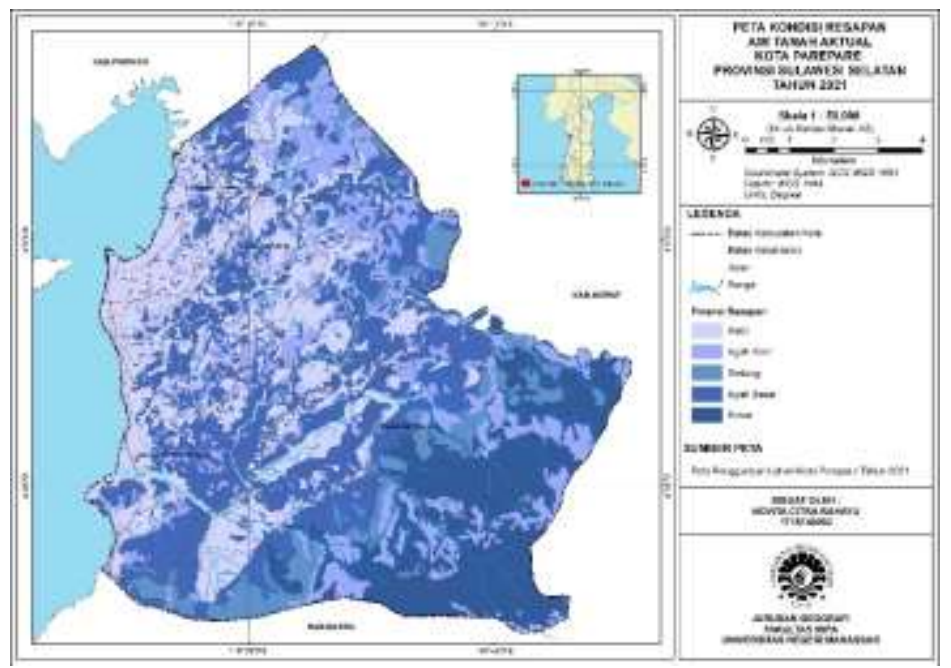

Gambar 8. Peta Kondisi Daerah Resapan Aktual Kota Parepare

Berdasarkan penggunaan lahan yang ada, Kota Parepare dapat dikelaskan menurut kemampuannya dalam meresapkan air untuk menentukan kondisi daerah resapan aktual. Kondisi daerah resapan aktual di Kota Parepare terbagi menjadi lima kelas kemampuan resapan yakni kecil, agak kecil, sedang, agak besar, dan besar. Adapun luas kondisi daerah resapan aktual Kota Parepare disajikan dalam Tabel 8 Berikut:

Tabel 8. Kondisi daerah resapan aktual di Kota Parepare

\begin{tabular}{|c|c|c|}
\hline Kemampuan Resapan & Luas $\left(\mathrm{km}^{2}\right)$ & Persentase (\%) \\
\hline Kecil & 24,04 & 24,56 \\
\hline Agak Kecil & 17,92 & 18,31 \\
\hline Sedang & 7,76 & 7,93 \\
\hline Agak Besar & 30,47 & 31,13 \\
\hline Besar & 17,69 & 18,07 \\
\hline
\end{tabular}

(Sumber: Hasil Analisis, 2021)

Selain kondisi resapan potensial, kondisi daerah resapan aktual juga memiliki peran penting dalan penentuan tingkat kekritisan daerah resapan yakni menunjukkan besarnya permintaan terhadap kawasan daerah resapan air dalam hal ini berdasarkan penggunaan lahan yang ada. Penggunaan lahan yang termasuk dalam kelas kemampuan kecil yakni permukiman, tambak, dan sawah. Kondisi permukaan yang tertutup bangunan mengakibatkan air lebih sulit untuk meresap ke dalam tanah dan mengakibatkan memiliki kemampuan yang rendah dalam meloloskan air. Kelas kemampuan resapan kecil memiliki luas lahan sebesar 24,04 $\mathrm{km}^{2}$ atau 24\% dari total luas Kota Parepare.

Kelas kemampuan resapan agak kecil memiliki luas $17,92 \mathrm{~km}^{2}$, penggunaan lahan yang termasuk dalam kelas ini adalah pertanian lahan kering. Kelas kemampuan reasapan sedang memiliki penggunaan lahan berupa semak belukar. Sedangkan kelas kemampuan resapan agak besar memiliki penggunaan lahan berupa perkebunan. Kelas kemampuan resapan agak besar ini merupakan kelas yang mendominasi kondisi resapan aktual Kota Parepare yakni seluas $30,47 \mathrm{~km}^{2}$. Adapun kelas kemampuan resapan besar dengan jenis penggunaan lahan kelas resapan tersebut berupa hutan memiliki luas wilayah dengan persentase sebesar 18,07\% dari total luas wilayah Kota Parepare.

\section{Tingkat Kekritisan Daerah Resapan Kota Parepare}

Tingkat kekritisan daerah resapan dipengaruhi oleh kondisi daerah resapan potensial dan kondisi daerah resapan aktual. Perbandingan antara kondisi daerah resapan potensial dan aktual dapat menunjukan tingkat kekritisan resapan di wilayah tersebut, sehingga peta tingkat kekritisan di Kota Parepare diperoleh dari hasil overlay antara peta kondisi daerah resapan aktual dan potensial Kota Parepare. 
Kondisi daerah resapan yang baik dicirikan dengan kondisi daerah resapan aktual dan potensial yang cenderung seimbang. Kondisi daearah resapan akan semakin kritis jika kondisi daerah resapan aktual tidak dapat mendukung potensi resapan. Seperti pada lahan dengan potensi resapan tinggi namun memiliki kondisi aktual berupa permukiman yang padat dan mengakibatkan air tidak dapat meresap sesuai dengan potensinya.

Tingkat kekritisan daerah resapan ditentukan berdasarkan matriks dalam Peraturan Menteri Kehutanan (P.32/MENHUT-II/2009) pada gambar 2 resapan potensial yang dinyatakan dengan huruf kecil dibandingkan dengan resapan aktual yang dinyatakan dengan huruf kapital untuk mengetahui tingkat kekritisan daerah resapan. Matriks tersebut menunjukan penurunan kondisi aktual akan memperburuk kondisi kekritisan daerah resapan.

Berdasarkan matriks tersebut, tingkat kekritisan daerah resapan di Kota Parepare memiliki 4 tingkat yakni baik, normal alami, mulai kritis, dan agak kritis yang tersebar secara acak. Adapun peta tingkat kekritisan daerah resapan di Kota Parepare disajikan dalam gambar 9.

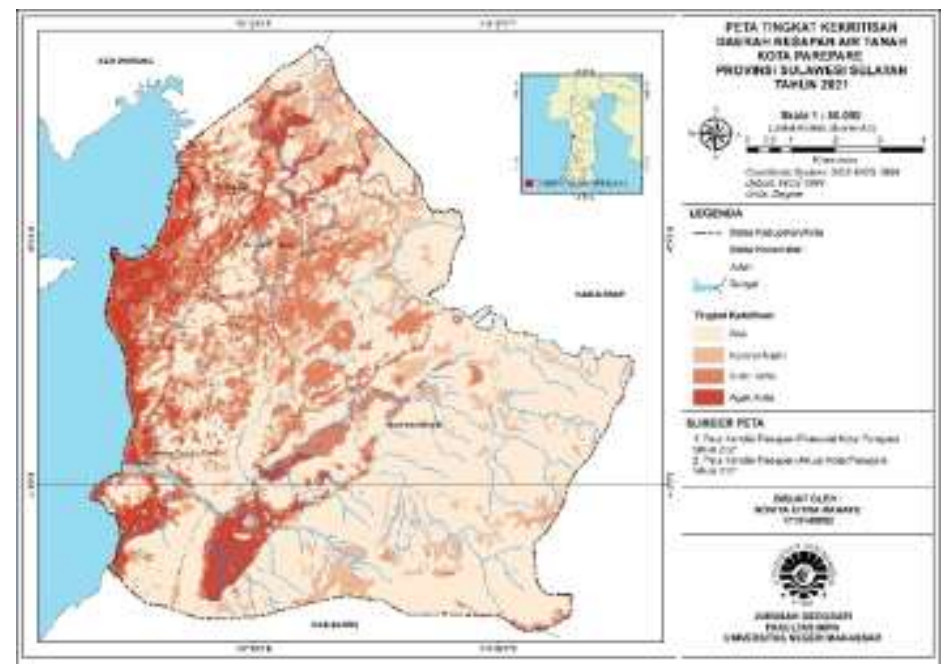

Gambar 9. Peta Tingkat Kekritisan Daerah Resapan Kota Parepare

Tingkat kekritisan baik terdapat pada daerah dengan kondisi daerah resapan aktual yang lebih baik atau kemampuan resapannya lebih besar dibandingkan dengan kondisi resapan potensialnya, seperti pada daerah dengan penggunaan lahan berupa hutan yang memiliki kondisi daerah resapan aktual yang besar. Kelas ini memiliki luas $59,24 \mathrm{~km}^{2}$ atau $60,50 \%$ dari total luas Kota Parepare. Kondisi resapan baik ini tampak banyak terdapat di bagian timur ke selatan Kota Parepare yang dominan merupakan Kecamatan Bacukiki. Hal yang paling mempengaruhi kondisi ini adalah penggunaan lahan di bagian hulu yang masih berupa hutan, sehingga kemampuan resapan yang besar.

Tingkat kekritisan daerah resapan kelas normal alami memiliki luas $13,29 \mathrm{~km}^{2}$ atau $13,57 \%$ dari total luas Kota Parepare. Tingkat kekritisan normal alami tampak dominan terdapat di bagian utara hingga tengah, dan sedikit tersebar secara acak pada bagian timur ke selatan Kota Parepare yang merupakan sebagian wilayah dari Kecamatan ujung dan sebagian wilayah dari Kecamatan Bacukiki. Kelas kekritisan ini diperngaruhi oleh kondisi resapan potensial dan aktualnya yang relatif seimbang sehingga besarnya permintaan terhadap kawasan daerah resapan dapat terpenuhi oleh potensi atau kemampuan kawasan resapan air itu sendiri.

Daerah resapan dengan tingkat kekritisan mulai kritis terjadi ketika nilai kondisi daerah resapan aktual turun setingkat dari kondisi potensialnya. Hal ini menunjukkan bahwa daerah tersebut memiliki kondisi aktual yang kurang mampu meresapkan air namun memiliki potensi resapan yang cukup baik. Dapat dilihat pada penggunaan lahan daerah ini didominasi oleh areal persawahan dengan jenis tanah regosol coklat yang memiliki tekstur tanah lempung. Seperti yang diketahui tekstur lempung memiliki kemampuan kurang baik dalam meloloskan air. Kelas kekritisan daerah resapan mulai kritis di Kota Parepare memiliki luas $17,46 \mathrm{~km}^{2}$ atau $17,83 \%$ dari total luas Kota Parepare. Hampir seluruh bagian wilayah Kecamatan Soreang dan Kecamatan Ujung didominasi oleh kondisi ini. 
Tingkat kekritisan paling tinggi di Kota Parepare yakni kelas agak kritis, dimana kelas ini merupakan kondisi daerah resapan yang paling dominan tampak pada bagian persisir utara ke selatan Kota Parepare. Tingkat kekritisan ini memiliki luas 7,93 $\mathrm{km}^{2}$ atau 8,10\% dari total luas Kota Parepare. Kondisi agak kritis ini umumnya terjadi karena pada daerah dengan potensi resapan yang cukup baik namun memiliki penggunaan lahan seperti sawah, permukiman, atau pertanian lahan kering yang memiliki kemampuan yang rendah dalam meloloskan air. Salah satu kecamatan yang memiliki kondisi resapan yang didominasi oleh kelas agak kritis adalah Kecamatan Soreang. Kondisi tersebut dipengaruhi oleh kondisi aktual di Kecamatan Soreang yang memiliki kemampuan resapan kecil karena dominasi penggunaan lahannya berupa permukiman, sehingga lebih rendah dua tingkat dari kondisi potensialnya yang didominasi oleh potensi resapan sedang. Adapun luas tingkat kekritisan daerah resapan di Kota Parepare disajikan dalam Tabel 9 berikut:

Tabel 9. Kondisi daerah resapan aktual di Kota Parepare

\begin{tabular}{lcc}
\hline \multicolumn{1}{c}{ Kemampuan Resapan } & Luas $\left(\mathrm{km}^{2}\right)$ & Persentase $(\%)$ \\
\hline Baik & 59,24 & 60,50 \\
Normal Alami & 13,29 & 13,57 \\
Mulai Kritis & 17,46 & 17,83 \\
Agak Kritis & 7,93 & 8,10 \\
\hline
\end{tabular}

(Sumber: Hasil Analisis, 2021)

Secara keseluruhan Kota Parepare memiliki kondisi resapan yang baik melihat hasil analisis menunjukkan lebih dari 50\% daerahnya memiliki kondisi daerah resapan yang baik. Kondisi ini perlu di pertahankan agar tidak menyebabkan terjadinya peningkatan tingkat kekritisan pada wilayah tersebut. Namun, meskipun luas wilayah dengan tingkat kekritisan yang baik lebih dominan daripada luas wilayah dengan tingkat kekritisan mulai kritis hingga agak kritis bukan berarti hal ini dapat dibiarkan begitu saja. Kondisi tersebut perlu lebih diwaspadai dan pengelolaan penggunaan lahan sebagai salah satu cara dalam mengatasi hal ini perlu lebih diperhatikan agar tidak meningkatkan tingkat kekritisan daerah resapan yang lebih serius. Kondisi peresapan yang baik tentu akan mempengaruhi sistem hidrologi untuk berfungsi dengan lebih baik pula. Sehingga segala bentuk kemungkinan terjadinya bencana hidrologis seperti banjir dan kekeringan dapat ditanggulangi dengan baik.

\section{SIMPULAN}

Berdasarkan hasil penelitian yang telah diperoleh oleh peneliti maka dapat disimpulkan bahwa : Kota Parepare memiliki kondisi daerah resapan potensial yang ditentukan berdasarkan kemiringan lereng yang diperoleh dengan memanfaatkan citra SRTM, jenis tanah, dan curah hujan yang kemudian menghasilkan 3 kelas potensi resapan yakni sangat kecil, kecil, dan sedang. Kelas potensi resapan kecil mendominasi dengan luas $69,07 \mathrm{~km}^{2}$ dan tersebar secara acak di Kota Parepare. Sedangkan kondisi daerah resapan aktual Kota Parepare ditentukan berdasarkan penggunaan lahan yang diperoleh dari pemanfaatan citra sentinel-2 dalam interpretasi dan survei lapangan dalam pembuatan peta penggunaan lahan yang menghasilkan 5 kelas kemampuan resapan yakni kecil, agak kecil, sedang, agak besar, dan besar. Kota Parepare didominasi oleh kemampuan resapan agak besar dengan luas 30,47 $\mathrm{km}^{2}$ berupa penggunaan lahan perkebunan. Tingkat kekritisan daerah resapan di Kota Parepare ditentukan berdasarkan hasil perbandingan kondisi daerah resapan aktual dan potensial. Kondisi resapan aktual yang semakin rendah dibandingkan dengan daerah resapan potensial meningkatkan tingkat kekritisan daerah resapan. Tingkat kekritisan daerah resapan di Kota Parepare menghasilkan 4 kelas yakni baik, normal alami, mulai kritis, dan agak kritis. Tingkat kekritisan baik mendominasi Kota Parepare dengan luas $59,24 \mathrm{~km}^{2}$ dan tersebar secara acak.

\section{DAFTAR RUJUKAN}

Adi, Rahardiyan Nugroho, dan Ogi Setiawan. 2009. Analisis Kekritisan Hidrologis Daerah Aliran Sungai untuk Perencanaan Pengelolaan DAS. Makalah pada Ekspose Hasil Litbang Teknologi Pengelolaan DAS dalam Upaya Pengendalian Banjir dan Erosi-Sedimentasi. Surakarta. 
BMKG. 2021. Data Curah Hujan. Badan Meteorologi Klimatologi dan Geofisika Wilayah IV Makassar. Kota Makassar.

DPUPR Kota Parepare. 2021. Arsip Data Izin Mendirikan Bangunan. Dinas Pekerjaan Umum dan Penataan Ruang Kota Parepare. Parepare: Pemerintah Kota Parepare.

Kementerian Kehutanan. 2009. Peraturan Menteri Kehutanan Republik Indonesia No: P. 32/MenhutII/2009. Tata Cara Penyusunan Rencana Teknik Rehabilitasi Hutan Dan Lahan Daerah Aliran Sungai $(R T k R H L-D A S)$. Jakarta.

Kohnke, H. 1968. Soil Physic. McGraw Hill. New York.

Mulyadi, M. 2019. Analisis Sumber-Sumber Air Pada Daerah Aliran Sungai (Das) Karajae Dalam Menunjang Ketersedian Air Baku Kota Pare-Pare. Agrotek: Jurnal Ilmiah Ilmu Pertanian, 3(2), 143-155.

Putri, N.P., dan Purwadio, H. 2013. Arahan Pengendalian Alih Fungsi Daerah Resapan Air Menjadi Lahan Terbangun di Kecamatan Lembang Bandung. Jurnal Teknik Pomits, 2(1),1-6.

RDTR Kota Parepare. 2020. Dinas Pekerjaan Umum dan Penataan Ruang Kota Parepare. Parepare: Pemerintah Kota Parepare.

Wirosoedarmo, R., Rahadi, B., \& Sasmito, D. A. 2007. Penggunaan sistem informasi geografi (SIG) pada penentuan lahan kritis di wilayah sub DAS Lesti Kabupaten Malang. Jurnal Ilmu-Ilmu Pertanian Indonesia. Edisi Khusus, 3, 452-456. 